\title{
CARACTERIZAÇÃO JURÍDICA DA DIGNIDADE DA PESSOA HUMANA
}

\author{
Antonio Junqueira de Azevedo \\ Professor Titular da Faculdade de Direito da \\ Universidade de São Paulo
}

\begin{abstract}
Resumo:
A acepção insular da pessoa; a concretização do princípio constitucional da dignidade humana à luz da nova ética; o princípio da dignidade humana é a consistência ao respeito aos pressupostos mínimos de liberdade e convivência entre os homens são alguns dos itens abordados neste trabalho pelo autor civilista.
\end{abstract}

\begin{abstract}
:
The person's insular meaning; the concretion of the constitucional principle fo human dignity towards a new ethics light; the principle fo human dignity is the consistence of the respect to the minimum pretexts of freedom and companionship between men are the itens approached in this article by the civilist author.
\end{abstract}

Unitermos: dignidade humana; nova ética; intangibilidade da vida humana; concretização da dignidade humana.

\section{Introdução.}

A utilização da expressão "dignidade da pessoa humana" no mundo do Direito é fato histórico recente. Muitas civilizações, graças a seus heróis e santos, respeitaram a dignidade da pessoa humana, mas juridicamente a tomada de consciência, com a verbalização da expressão, foi um passo notável dos tempos mais próximos. ' "Da dignidade da pessoa humana tornam-se os homens de nosso tempo sempre mais cônscios" ("Declaração Dignitatis Humanae Sobre a Liberdade Religiosa" de Paulo VI e do Concílio Vaticano II, em 7 de dezembro de 1965). Tomada em si, a expressão é um conceito jurídico indeterminado; utilizada em norma, especialmente

1. Parcec que a expressão $\mathrm{em}$ causa surgiu pela primcira vez, nesse contexto preceptivo $\mathrm{cm}$ que hoje está scndo usada, cm 1945, no "Preâmbulo" da Carta das Naçõcs Unidas ("digniclade e valor do ser humano"). A palavra "dignidadle", porćm, utilizada em contcxto ćtico, não-juridico, para o ser humano, já cstá muito precisamente cm Kant, que opõc "prę̧o" "Preis", para tudo que serve de mcio, à "dignidade", "Würde", para o que ć um fim cm si mesmo, o valor intrínscco do ser racional (para o citado filósofo, somente o homem está nessa condição). Citamos Kant por via de tradução francesa dos "Fundamentos da Metafisica dos Costumes" (p. 80). Os dados completos de todas as citações cstão na bibliografia final. 
constitucional, é princípio jurídico. ${ }^{2}$ É sob essa última caracterização que está na Constituição da República, eis que aí aparece entre os "principios fundamentais" (art. $1^{\circ}$, III).

Com ligeiras diferenças de redação, também utilizam a expressão, exemplificativamente: 1. a Declaração Universal dos Direitos do Homem (1948), tanto em seu primeiro "considerando" quanto em seu primeiro artigo. "Considerando que o reconhecimento da dignidade inerente a todos os membros da família humana e de seus direitos iguais e inalienáveis é o fundamento da liberdade, da justiça e da paz no mundo" E art. 1": "Todos os homem nascem livres e iguais em dignidade e direitos. São dotados de razão e consciência e devem agir em relação uns aos outros com espirito de fraternidade"; 2. a Constituição da Republica Italiana (1947): "Todos os cidadãos têm a mesma dignidade social e são iguais perante a lei sem distinção de sexo, raça, língua, religião, opinião politica e condições pessoais e sociais" (art. 3", 1 " parte); 3. a "Lei Fundamental" da Alemanha (1949): "A dignidade do homem é intangível. Respeitá-la e protegê-la é obrigação de todo o poder público" (art. 1.1); 4. a Constituição da República Portuguesa: "Portugal é uma República soberana, baseada, entre outros valores, nadignidade da pessoa humana e na vontade popular e empenhada na construção de uma sociedade livre, justa e solidária" (art. $\left.1^{\circ}\right){ }^{3} \mathrm{E}$ : "Todos os cidadãos têm a mesma dignidade social e são iguais perante a lei" (art. 13., 1" alínea).

Infelizmente, porém, o acordo sobre palavras, "dignidade da pessoa humana", já não esconde o grande desacordo sobre seu conteúdo. Há hoje duas diversas concepções da pessoa humana que procuram dar suporte à idéia de sua dignidade; de um lado, há a concepção insular, ainda dominante, fundada no homem como razão e vontade, segundo uns, como autoconsciência, segundo outros - é a concepção para cujo fim queremos colaborar porque se tornou insuficiente, - e, de outro, a concepção

2. Os conccitos juridicos indeterminados são assim chamados porque scu contcúdo ć mais indetcrminado que o dos conccitos juridicos determinados (excmplo destes, os numéricos, - dezoito anos, 24 horas -, daqueles, "casa particular"). Os conceitos jurídicos indeterminados podem ser descritivos (cx. patrimônio, cobrança) ou normativos (cx. justa causa, boa-fé) (cf. Engish, "Introdução ao Pensamento Jurílico", 1988, p. 210). Os normativos exigem valoração. No caso da dignidade humana, o conceito, alćm de normativo, ć axiológico porque a dignidade humana ć valor - a dignidade ć a cxpressão do valor da pessoa humana. Todo "valor" ć a projeção de um bem para alguém; no caso, a pessoa humana ć o bem c a dignidadc, o scu valor, isto ć, a sua projeção. Principio juridico, por sua vez, é a idćia dirctora de uma regulamentação (Cf. Larenz, "Derecho justo", 1985, p. 32). O princípio juridico nào ć regra, mas ć norma juridica; exige nào-somente interpretação, mas tambćm concretização.

3. A redação de 1976 , repetida cm 1982, por ocasião da primcira revisão, cra: "Portugal é uma República soberana, baseada na dignidade da pessoa humana e na vontade popular e empenhada na sua transformação numa sociedlade sem classes". Depois, cm 1989 (2 $2^{4}$ revisào), a redação passou a: "Portugal é uma República soberana, baseada na dignidade da pessoa humana e na vontade popular e empenhada na construção de uma sociedade livre, justa e soliclária". Hojc, após a 3" revisào, o teor do art. 1" ć o que consta do texto supra. O artigo "O Direito Brasileiro e o Principio dla Dignidade Humana". de Nobre Júnior (2001), cnumera diversas outras Constituições que abrigam o princípio da dignidade. O livro " $A$ Afirmação Histórica dos Direitos Humanos", de Comparato (2001), por sua vez, traz c comcnta as mais importantes declarações de dircitos humanos. 
própria de uma nova ética, fundada no homem como ser integrado à natureza, participante especial do fluxo vital que a perpassa há bilhões de anos, e cuja nota específica não está na razão e na vontade, que também os animais superiores possuem, ou na autoconsciência, que pelo menos os chimpanzés também têm, e sim, em rumo inverso, na capacidade do homem de sair de si, reconhecer no outro um igual, usar a linguagem, dialogar e, ainda, principalmente, na sua vocação para o amor, como entrega espiritual a outrem. A primeira concepção leva ao entendimento da dignidade humana como autonomia individual, ou autodeterminação; a segunda, como qualidade do ser vivo, capaz de dialogar e chamado à transcendência.

Do ponto de vista ontológico, ou de visão da realidade, a concepção insular da pessoa humana é dualista: homem e natureza não se encontram, estão em níveis diversos; são respectivamente sujeito e objeto. O homem, "rei da criação" vê e pensa a natureza. Somente o homem é racional e capaz de querer. O homem é radicalmente diferente dos demais seres; somente ele é auto-consciente. A natureza é fato bruto, isto é, sem valor em si. A segunda é monista: entre homem e natureza, há um continuum; o homem faz parte da natureza e não é o único ser inteligente e capaz de querer, ou o único dotado de autoconsciência. Há, entre os seres vivos, um crescendo de complexidade e o homem é o último elo da cadeia. A natureza como um todo é um bem. E a vida, o seu valor.

Do ponto de vista antropológico, em segundo lugar, o homem não é u'a "mente", que tem um corpo; ele todo é corpo. O racionalismo iluminista, que deu origem à concepção insular, corresponde visualmente à figura do homem europeu: o terno que veste deixa-lhe à mostra somente a cabeça e as mãos (= razão + ação, ou vontade); o resto do corpo é a parte oculta do iceberg, - a natureza física, cuja essência, no homem, aquela filosofia ignora. ${ }^{4}$ Essa parte do corpo - (entre parêntesis, observamos que insensivelmente "o corpo" é pensado por nós muitas vezes à européia, como sendo a parte de nosso ser que não é a cabeça) - essa parte do corpo, repetimos, é considerada uma "máquina" ou um "mecanismo" tido pela mente. Mas a mente também é corpo!

O desconhecimento do valor da natureza, inclusive da natureza no homem, é, assim, a primeira grande insuficiência de concepção insular. A segunda é, justamente, seu caráter fechado, subjetivista. Quer como razão e vontade, quer como autoconsciência, a concepção insular age com redução da plenitudo hominis, retirando

4. O presentc texto resulta de comunicação feita $\mathrm{cm}$ congresso rcalizado $\mathrm{cm}$ Ouro Prcto, onde há, $\mathrm{cm}$ algumas igrejas, "santos de roca" da ćpoca do lluminismo; cssas imagens também servem muito bem para ilustrar a concepção insular da pessoa humana: somente ten cabeça c mãos, o resto ć "roupa". Não deixa de ser curioso obscrvar como cssas imagens não são apreciadas pelos brasilciros. É claro - clas não correspondem à nossa formação a fricana c indigena que valoriza o corpo c a vida. Jorge Miranda ("Manual de Dircito Constitucional", IV, p. 36) assim sc cxpressa sobrc os valores da Á frica tradicional: " $A$ inviolabilidade da vida e a entreajuda dos membros da comunidade são os valores findamentais da ordem colectiva. Procura-se, acima de tudo, a vida em harmonia com os outros, com a Natureza e com os espíritos que a povoam e animam". Nesse sentido, a nova ćtica, que defendemos, por ser mais abrangente, ć atć mesmo mais "brasileira" que a insular scmpre tão "européia". 
do ser humano justamente o que ele tem de realmente específico: seu reconhecimento do próximo, com a capacidade de dialogar, e sua vocação espiritual.

Apesar dos desvios, dos rumos dispersos, dos caminhos sem saída, a evolução dos seres vivos, vista a longuíssimo prazo, revela aumento progressivo de complexidade - dos seres unicelulares, como a bactéria, aos pluricelulares, passando aos vegetais, aos animais invertebrados, aos vertebrados, e vindo até o homem. Entre o mais remoto e o mais recente dos seres, há mudanças de nível com a emergência de novas faculdades, sempre, porém, sem quebra da continuidade: à simples vida, foram se acrescentando a mobilidade, a sensibilidade, a inteligência e a vontade, a autoconsciência e, finalmente, a projeção para o próximo, com a capacidade de dialogar, e a potencial abertura para o absoluto. ${ }^{5}$ Ao tentar fixar a especificidade do homem, a concepção insular pára na inteligência e na vontade, que são faculdades comuns aos homens e animais superiores, ou pára na autoconsciência, comum pelo menos ao homem e ao chimpanzé. ${ }^{6}$ O que, de fato, é específico do homem é omitido por ela. Daí, com graves conseqüências jurídicas, o lento deslizar intelectual no entendimento da dignidade

5. Do início da vida na Tcrra atć a projeçào para o próximo, com o uso da linguagem, há um continumm (imanĉncia). A abertura para o absoluto ć potencial; para transformá-la $\mathrm{cm}$ ato ć preciso uma decisão fundamental, amar. Amar ć a decisão fundamental que inventa a transcendência.

6. A autoconsciência ć atribuida pcla ctologia tambćm aos chimpanzćs (c talvcz aos orangotangos) especialmente por causa da chamada "cxperiência do cspelho" "Enquanto quase todlos os mamiferos que se orientam pela visão tentam inicialmente pesquisar ou olhar atrás do espelho, somente duas espécies não-humanas de mamiferos - chimpanzés e orangotangos-parecem entender que eles estäo se vendo no espelho. Essa situação especial desses macacos é conhecida há muito tempo. Em 1922. Autan Pertielje. um naturalista holandês, observou que, enquanto os simios' não compreendiam a relação entre sua imagem e eles mesmos, um orangotango olhava atentamente em primeiro lugar para sua imagem no espelho mas então também para o que estava atrás de si e sua crosta de comida no espelho ... obviamente entendendo o uso do espelho.

De modo semelhante, o psicólogo de orientação "gestalt", Wolfgang Köhler; em 1925, comentou a respeito do profundo interesse dos chimpanzés por sua própria imagem; eles continuavam a brincar com o espelho, fazendo faces estranhas para si mesmos e testando os objetos refletidos com o objeto real. olhando para a fiente e para trás entre os dois. Simios, pelo contrário, reagiam com expressóes faciais sem significado: vian seu próprio reflexo como de outro individuo. tratando-o como um estranho de seu próprio sexo e espécie.

Uma evidência convincente derivou de uma sofisticada experiência de Gordon Gallıp, um psicólogo comparatista americano. Um individuo recebia, sem se dar conta, uma mancha de tinta num lugar. especifico, como sobre a sobrancelha, invisivel sem o espelho. Guiado por sua imagem refletida. chimpanzés e orangotangos - como as crianças com mais de 18 meses - esfiegavam a mancha com sua mão e olhavam os dedos que tinham sido usados, reconhecendo que a mancha colorida estava no próprio rosto. Outros primatas - como crianças com menos de 18 meses - não faziam essa conexão. Gallup foi a ponto de equiparar auto-reconhecimento com autoconsciência, e esta, por sua vez, com míltiplas habilidades mentais. A lista dessas habilidades inclui atribuição de intenção aos outros, enganos intencionais aos outros, reconcilią̧ão e empatia. Em restumo, scres humanos c macacos supcriores ("apes") cntram num terreno cognitivo que os coloca à parte de outras formas de vida" (De Waal, "Good Natured". 1996, p. 67). No original: "While almost all visually oriented mammals initially try to reach or look behind a mirror, only two nonhumman species - chimpanzees and orangutans - seem to understand that they are seeing themselves. The special status of these apes has been recognized for a long time. In 1922 Anton Pertielje, a Dutch naturalist, remarked that, whereas monkeys fail to understand the relation between 
da pessoa humana, de "autonomia individual", para "qualidade de vida", quando, então, algo que deveria ser radical passa a ser tão relativo quanto viver melhor ou pior. A concepção insular, antropocêntrica e subjetivamente fechada, já não garante juridicamente o ser humano; infelizmente, ela pode levar a abusos e desvios, entre os quais o caso da eutanásia é paradigmático.?

Se as concretizações jurídicas da dignidade segundo ambas as concepções são muitas vezes idênticas, em pontos fundamentais divergem radicalmente. Seguese, então, por força desse diverso entendimento do que seja pessoa humana, um absurdo jurídico: o mesmo texto normativo constitucional, usado para fundamentar tanto a permissão da introdução quanto a proibição da introdução, da eutanásia, do abortamento, da pena de morte, da manipulação de embriões, do exame obrigatório de DNA, da proibição de visitar os filhos etc. "A confusão é geral" (Machado de Assis).

É preciso, pois, aprofundar o conceito de dignidade da pessoa humana. A pessoa é um bem e a dignidade, o seu valor. ${ }^{8}$ O Direito do século XXI não se contenta

their reflections and themselves, an orangutan attentively looks firstly at his mirror image, but then also at his behind and his crust of bread in a mirror... obviously understanding the use of a mirror:

Similarly, the German gestalt psychologist Wolfgang Köhler in 1925 commented on the lasting interest of chimpanzees in their mirror image; they continue to play with it, making strange faces at themselves and checking reflected objects against the real thing by looking back and forth between the two. Monkeys;, in contrast, react with facial expressions that are anything but firivolous: they regard their reflection as another individual, treating it as a stranger of their own ser and species.

Compelling evidence was derived in the 1970s from elegant experiments by Gordon Gallup, an American comparative psychologist. An individual unknowingly received a dot of paint in a specific place, such as above the eyebrow, invisible without a mirror: Guided by their reflection, chimpanzees and orangutans - as well as children more than eighteen months of age - rubbed the painted spot with their. hand and inspected the fingers that had touched $i$, recognizing that the coloring on the reflected image was on their ows face. Other primates - and younger children-failed to make this connection. Gallup) went on to equate self-recognition with self-awareness, and this in turn with a multitude of sophisticated mental abilities. The list encompassed attribution of intention to others, intentional deception. reconciliation, and empathy. Accordingly, humans and apes have cntered a cognitive domain that sets them apart from all other forms of life" (De Waal, "Good Natured", 1996, p. 67).

7. Escreve Eticnne Montero ("Cahiers", n. 3, 1998) contra a chamada "cutanásia dircta": "A algunns agradaria fazer-nos crer que, ao privilegiar o respeito à autonomia individual (cada um é juiz da sua própria dignidade e decide o momento de sura morte), a legalização é a innica solução admissivel em um estado pluralista e laico. Mas estão muito equivocalos: ao plasmar em um texto legal - cuja vocação é estruturar comportamentos - o principio da eutanásia, inclusive a voluntária, o legislador avalizaria a controvertida noção de "yualidade de vida", impondo-a todos"

8. A concretização da idéia de dignidade da pessoa humana cxige um tomada de posição implicita ou cxplícita sobre o que scja "pessoa humana". A ćtica supõc a antropologia (filosófica). "Esta cs la razón por la que la historia de la filosofia cs la historia del encuentro secular entre antropologia y ética. La rama de la ciencia que tiene como objetivo el estudio global del bien y del mal moral-éstos son los objetivos de la ética - no puede prescindir del hecho de que el bien y el mal se manifiestan en las acciones, y a através de las acciones se convierten en parte del hombre. Se pueden encontrar ejemplos tan antiguos como la Etica a Nicómaco. Y aunque en la filosofia moderna, especialmente en el pensamiento filosófico contemporáneo, existe una clara tendencia de la antropologia (este terreno está ahora sometido a la exploración de la psicologia y la sociologia moral), no es posible eliminar completamente las implicaciones antropológicas de la ética" (Karol Wojtyla, "Persona y acción", 1982, p. 13). 
com os conceitos axiológicos formais, que podem ser usados retoricamente para qualquer tese. Mal o século XX se livrou do vazio do "bando dos quatro"- os quatro conceitos jurídicos indeterminados: função social, ordem pública, boa-fé, interesse público 9 -, preenchendo-os, pela lei, doutrina e Jurisprudência, com alguma diretriz material, que surge, agora, no século XXI, problema idêntico com a expressão "dignidade da pessoa humana"! No presente artigo, após a crítica da dignidade como autonomia individual, fundada na concepção insular da pessoa humana (parte "II", a seguir), faremos uma tentativa de determinação do conteúdo da dignidade, segundo uma nova ética - a ética da vida e do amor - (parte "III").

\section{A concepção insular de pessoa.}

Em pelo menos três áreas, o avanço do conhecimento científico pôs abaixo a visão insular da pessoa. Essas áreas são: a biologia, com a explicação da evolução das espécies; a etologia - estudo do comportamento dos animais na natureza -, especialmente a primatologia, com o aprimoramento das observações; e as ciências cognitivas, com as descobertas sobre o cérebro humano.

Após indagar para si mesmo o que é o homem, o zoologista G. G. Simpson escreveu: "O ponto que quero agora deixar registrado é que todas as tentativas para responder a essa questão feitas antes de 1859 são sem nenhum valor ("worthless") $e$ é melhor que as ignoremos completamente" (apud Richard Dawkins, "The Selfish Gene", 1998, p. 1). De fato, desde 1859, ano da publicação da "Origem das Espécies" qualquer idéia do homem como ser desvinculado de uma ancestralidade primata tornouse insustentável. As pesquisas paleontológicas, no ponto a que chegamos, com a certeza da sucessão dos diversos tipos de antropóides (a partir de 35 milhões de anos) e, em seguida, dos vários tipos de hominóides (a partir de 25 milhões de anos), depois os hominídeos (há seis ou cinco milhões de anos), até chegar às muitas espécies do gênero homo (desde aproximadamente 2,5 milhões de anos $h$. habilis, $h$. erectus, $h$. neanderthalensis, $h$. sapiens arcaico etc.), e, finalmente, ao moderno homo sapiens (mais ou menos 150 mil anos atrás), não permitem aquela conclusão dos sábios iluministas de que somente o homem é dotado de razão e vontade. Da bipedia (entre oito e cinco milhões de anos) à utilização de instrumentos de pedra (2,5 milhões de anos), do aumento do cérebro (iniciada há 2,5 milhões de anos) à descoberta do fogo (700 mil), daí à linguagem (¿"protolinguagem" com o homo habilis e linguagem somente com o moderno homo sapiens?) e aos cuidados especiais com os mortos (100 mil anos), são sempre alguns milhares de anos de evolução, demonstrando, numa

9. O conccito de função social veio a ter, afinal, dirctrizes materiais na própria Constituição da República (art. 182 c scus $\$ \$$ c art. 186); o de ordem pública, com a divisão doutrinária cntre ordem pública de dircção, $\mathrm{cm}$ decadência, $\mathrm{c}$ ordem pública de proteção, $\mathrm{cm}$ ascensão, c, ainda, com a scparaçào das leis de ordem pública, do princípio de ordem pública, ganhou precisão. $\mathrm{O}$ de boa-fé foi tão traballuado pela doutrina que dispensa comentários. Do "bando dos quatro", somente o conceito de "interesse público" mantćm, ainda, infelizmente, grande indefiniçào. 
determinada linha de primatas, o progressivo aumento das faculdades existenciais. Essas emergências vitais da evolução vão colocando os novos seres em níveis cada vez mais elevados de complexidade. Não é possível, portanto, manter a convicção de que aquelas faculdades (razão, vontade, autoconsciência) já teriam surgido no homem prontas como as conhecemos hoje, tal qual Minerva da cabeça de Júpiter, ou seja, que ou teriam sido criadas com o próprio homem em um momento único, ou teriam sido acrescentadas a um "suporte" (o macaco ancestral), de repente, não se sabe bem como.

Acresce a isso que a etologia comprova o que qualquer bom observador, não contaminado pelo racionalismo europeu, sabe: animais, como burros, cavalos, cachorros, macacos, pensam e querem. É de se ver com que persistência os burros se esforçam para fazer o que desejam! E como é comum crianças de fazenda se queixarem aos pais de que o cavalo em que estão montadas "só pensa em comer"!10 Os cachorros, por sua vez, como seus donos sabem, têm consciência do que é proibido e do que é permitido; envergonham-se quando erram e orgulham-se quando acertam. São impressionantes, por fim, os relatos de solidariedade, amizade e colaboração entre os macacos antropóides ("apes" - chimpanzés, gorilas, orangotangos)! (cf. as exposições feitas por De Waal, "Good Natured" 1996, passim)."

Nesse campo, não têm nenhuma razão grandes nomes da filosofia, como Descartes e Kant, o primeiro, ao afirmar que os animais são "máquinas que se movem" e o segundo, ao reduzi-los a "coisas". Descartes, depois de escrever que a alma é que pensa e que os animais não têm alma e, portanto, não pensam, nem tem vontade, transforma-os em "robots" naturais ("autômatos" na sua linguagem). "O que não parecerá nada estranho às pessoas que, sabendo como a indústria dos homens pode fazer autômatos, ou máquinas móveis, empregando poucas peças, comparando com a

10. É preciso não confundir vontade (= capacidade interna de decisão) c libcrdade (liberdade natural). Admitamos, para argumentar, que a vontade dos animais não ć livre - as decisõcs dos animais scriam detcrminadas pcla naturcza c suas circunstâncias -... mas, perguntamos, não scria cssa a mcsma situação, somente mais complexa, a do homem? A diferença não scria somente de grau? Um computador aperfeiçoadissimo, alimentado com todos os dados de uma situação c mais todos os dados individuais de algućm (dados genćticos, o passado vivido c registrado psicologicamente, o atual cstado físico) não revelaria previamente que decisão cssc algućm tomaria naquela situação? Com exceção do ato fundamental da libcrdade moral, amar ou não amar (ver nota 5), c a possibilidade de praticar os atos com amor ou scm amor, havcria mesmo liberdade (liberdade natural)? Com exceção da capacidade de amar; parece que ou os animais superiores, como o homem, têm alguma liberdade de querer, variando a extensão do "espaço de escolha" de cada um, ou nenhum dos dois têm nenhuma.

11. O autor citado no texto, a propósito de macacos alcijados ou mentalmente prejudicados, mas perfeitamente integrados no grupo, chega a se referir a uma "survival of the unfittest" ("sobrevivência dos inaptos"). "O altuismo não é exclusivo da nosso espécie. De fato, sua presença em outras espécies, e o teorético desafio que isso representa, é o que deu origem à sociobiologia - o estudo contemporâneo do comportamento animal (inclusive humano) de uma perspectivas evolucionista. Ajudar os outros a um custo ou risco de si mesmo ć algo muito difundido no mundo animal ("Good Naltured", p. 12). "Allruism is not limited to our species. Indeed, its presence in other species, and the theoretical challenge this represents, is what gave rise to socibiology - the contemporary studly of animal (including human) behavior from an evolutionary perspective. Aiding others at a cost or risk to oncself is widespread in the animal world" ("Good Natured", p. 12). 
pluralidade de ossos, músculos, nervos, artérias, veias e todas as demais partes do corpo animal, considerarão esse corpo como uma máquina que, tendo sido fabricada pelas mãos de Deus, é incomparavelmente melhor ordenada e tem em si movimentos mais admiráveis que qualquer uma das que podem ser inventadas pelos homens" 12 ("Discours de la méthode", $5^{\text {a }}$ parte). Como diz Hans Jonas ("Le principe responsabilité", 1995, p. 127), é inegável a presença de "elementos subjetivos" no agir e sofrer dos animais; negar essa presença é uma "violência dogmática" E, sobre essa negação ideológica cartesiana da subjetividade animal, escreve: "Mas a razão totalmente artificial de tal negação, a saber o decreto de Descartes (sic) de que a subjetividade como tal somente pode ser racional e, portanto, existir somente no homem, não convence o observador razoável e qualquer proprietário de cachorro poderá zombar dessa observação"'l3

Kant, por sua vez, escreve: "Todos os objetos de nossas inclinações têm somente um valor condicional, porque, se as inclinações e as necessidades que delas derivam não existissem, esses objetos seriam sem valor. Mas as próprias inclinações ou as fontes de nossas necessidades tampouco têm um valor absoluto e tampouco merecem serem desejadas por si mesmas que todos os seres racionais devem querer se livrar inteiramente delas. Assim, o valor de todos os objetos, que nós podemos conseguir por nossas ações, é sempre condicional. Os seres, cuja existência não depende de nossa vontade, mas da natureza, têm somente, se são seres privados de razão, um valor relativo, o de meios, e eis por que são chamados de coisas, enquanto que, ao contrário, dá-se o nome de pessoas aos seres racionais, porque sua própria natureza os fez como fins em si, isto é, algo que não pode ser empregado como meio, e que, em conseqüencia, restringem na mesma proporção a liberdade de cada um (e, por sua $v e z$, lhe é um objeto de respeito) $1 / 4-15$

12. No original: "Ce qui ne semblera nullement étrange à ceux qui, sachant combien de divers automates, ou machines mouvantes, l'industrie des hommes peut faire, sans y employer que fort peu de pièces, à comparaison de la grande multitude des os, des muscles, des nerfs, des artères, des veines, et de toutes les autres parties qui sont dans le corps de chaque animal, considćrcront ce corps comme unc machine qui, ayant été faite des mains de Dieu, est incompareblement mieux ordonnée, et a en soi des mouvements plus admirables, qu'aucune de celles qui peuvent être inventées par les hommes" Sobre as considerações de Descartes c de scus scguidores, a respeito dos animais, v. Gonticr, "De l'homme à l'animal". passim.

13. No original: "Mais la raison totalment artificielle d'une telle négation, à savoir le décret de Descartes (sic) que la subjectivité comme telle peut seulement être raisonnable et doit donc exister seulement dans l'homme, ne lie pas l'observateur raisonnable et n'importe quel propriétaire de chien pourra s'en gausser" (rcforços gráficos nossos).

14. No original: “Tous les objets des inclinations n'ont qu'une valeur conditionelle; car si les inclinations et les besoins qui en dérivent n'existaient pas, ces objets seraient sans valeur. Mais les inclinations mêmes, ou les sources de nos besoins, ont si peu une valeur absolue et méritent si peu d'être désirées pour elles-mêmes, que tous les êtres raisonnables doivent souhaiter d'en être entièrement délivrés. Ainsi la valeur de tous les objets, que nous pouvons nous procurer par nos actions, est toujours conditionnelle. Les êtres dont l'existence ne dépend pas de notre volonté, mais de la nature, n'ont aussi, si ce sont des êtres privés de raison, qu'une valeur relative, celle de moyens, et c'est pourquoi on les appelle 
Felizmente, o BGB, seguindo o Código Civil austríaco, é hoje bem mais realista; em 1990, seu texto foi alterado: o título "Coisas" (Sachen) da Parte Geral passou a ser "Coisas. Animais" (Sachen. Tiere) e o $\$ 90$ atualmente dispõe: "Os animais não são coisas. Os animais são tutelados por lei especifica. Se nada estiver previsto, aplicam-se as disposições válidas para as coisas" Além disso, em caso de dano ao animal ( $\$ 251.2)$, o juiz não pode recusar a tutela específica, ainda que os custos da cura sejam maiores que o valor econômico hipotético do animal.

Finalmente, as ciências cognitivas, por vários meios, especialmente pela observação das conseqüências de lesões cerebrais acidentais, ${ }^{16}$ pela realização de ressonância magnética e de eletroencefalografia, pela utilização dos processos PET (câmaras de pósitrons), ${ }^{17} \mathrm{e}$, finalmente, pela conjugação das análises químicas e dos estados mentais ${ }^{18}$, têm, com alguma segurança, comprovado que os processos de sensações, ordenação das sensações e impressões internas (pensamentos) são físicos ou no mínimo tem total correspondência física.

É patente, pois, a insuficiência teórica da concepção da pessoa humana como ser auto-consciente, racional e capaz de querer. Fundamentar toda a nossa dignidade numa "autonomia" individual, que, além de duvidosa, não é evidentemente absoluta e acaba sendo vista somente como "qualidade de vida" a ser decidida subjetivamente, não basta.

A enormidade dos avanços da tecnologia chegou a um ponto que não só põe em perigo a vida do planeta, como, no que diz respeito ao tema desse artigo, permite a plena manipulação da natureza humana, por meio da biomedicina. A velha

des choses, tandis qu'au contraire on donne le nom de personnes aux êtres raisonnables, parce que leur nature même en fail des fins en soi, c'est-à-dire quelque chose qui ne doit pas être employé comme moyen, et qui, par conséguent, restreint d'autant la liberté de chacun (et lui est un objet de respect)"

15. O trecho de Kant nos "Fundamentos da Metafisica dos Costumes" é muito citado porque, a todos os personalistas, agrada a idćia do homem como fim, c nunca como mcio. Isto cstá bcm, mas Kant, alćm dos crros filosóficos de negar valor $\mathrm{cm}$ si à naturcza $\mathrm{c}$ à vida $\mathrm{cm}$ geral c de incluir os animais cntre as "coisas" - csse crro ć, hoje, crro também juridico cm scu próprio pais -, cxpressa a idćia de pessoa como fim, sem ligação lógica com a moral formal que ele sustenta com base no imperativo categórico. Sua concepção de pessoa - certa, no resultado - não se deduz de scus raciocínios formais. "En vérité, doit-on ajouter, l'intuition morale de Kant était plus grande que ce que dictait la logique du système. Le vide particulier auquel conduit "l'impératif catégorique" purement formel avec son critère de la possibilité d'universaliser sans contradiction la maxime du vouloir, a été remarqué maintes fois. Mais Kant luimême rachetait le simple formalisme de son impératif catégorique par um principe de comportement "matériel" qui prétendument en découle, alors qu'en vérité il lui est surajouté: le respect de la dignité des personnes en tant qu'elles sont leurs propres fins. Le reproche de vide ne vaut certainement pas pour cela!"

16. O caso mais célcbre ć o de Phincas Gage que sobreviveu à lesão cercbral causada por barra de ferro, cm 1868 (cf. Jean-Pierre Changcux et Paul Ricocur, "Ce qui nous fail penser", p. 172). Mas, depois, as obscrvações se multiplicaram (cf. Antonio Damásio, "O Mistério da Consciência", passim).

17. Cf. Changeux ct Ricocur, p. 62.

18. Entra aqui toda a questão dos ncurotransmissores (cf. Master c McGuirc "The Neuro-transmitter" Revolution", passim), de que, apcsar de sua importância, não trataremos para não cansar o lcitor. 
ética já não resolve essas novas situações. Diferentemente, conforme a ética da vida e do amor, as soluções existem.

O princípio jurídico da dignidade fundamenta-se na pessoa humana e a pessoa humana pressupõe, antes de mais nada, uma condição objetiva, a vida. A dignidade impõe, portanto, um primeiro dever, um dever básico, o de reconhecer a intangibilidade da vida humana. Esse pressuposto, confọme veremos adiante, é um preceito jurídico absoluto; é um imperativo jurídico categórico. Em seguida, numa ordem lógica, e como conseqüência do respeito à vida, a dignidade dá base jurídica à exigência do respeito à integridade física e psíquica (condições naturais) e aos meios mínimos para o exercício da vida (condições materiais). Finalmente, a mesma dignidade prescreve, agora como conseqüência da especificidade do homem, isto é, de ser apto ao diálogo com o próximo e aberto ao amor, o respeito aos pressupostos mínimos de liberdade e convivência igualitária (condições culturais). Os três últimos preceitos (respeito à integridade física e psíquica, às condições mínimas de vida e aos pressupostos mínimos de liberdade e igualdade), como é próprio dos preceitos deduzidos dos princípios jurídicos, não são imperativos categóricos; embora fundamentais, na sua qualidade de requisitos mínimos para o desenvolvimento da personalidade e procura da felicidade, não são imperativos radicais, são imperativos juridicos relativos. Além disso, devem ser obedecidos segundo sua hierarquia.

3. Concretização do princípio constitucional da dignidade humana à luz da nova ética.

A vida genericamente considerada consubstancia o valor de tudo que existe na natureza. Esse valor existe por si; ele independe do homem. Do primeiro ser vivo até hoje, há um fluxo vital contínuo; todo ser vivo tem sua própria centelha de vida, mas cada centelha individual surge do fogo que, desde então, queima na Terra e, nesse fogo, cada centelha se insere como parte no todo. A vida em geral fundamenta o Direito Ambiental e o Direito dos Animais. Todavia, é, sem dúvida, a vida humana, que, sob o aspecto ontológico, representa sua parte excelente. Por isso, a vida humana - globalmente e em cada uma de suas centelhas - deve merecer a maior atenção do jurista. Sob o ponto de vista que nos interessa, isto é, de cada pessoa humana, a vida é condição de existência. O princípio jurídico da dignidade, como fundamento da República, exige como pressuposto a intangibilidade da vida humana. Sem vida, não há pessoa, e sem pessoa, não há dignidade.

O pressuposto de um princípio não é uma conseqüência do princípio; sua exigência é radical. Um princípio jurídico, ao se concretizar, exige sempre um trabalho de modelação para adaptação ao concreto; nesse trabalho, a intensidade da concretização poderá ser maior ou menor. Até mesmo um princípio fundamental, como o da dignidade da pessoa humana, impõe o trabalho de modelação porque, por exemplo, é preciso compatibilizar a dignidade de uma pessoa com a de outra (e, portanto, alguma coisa da dignidade de uma poderá ficar prejudicada pelas exigências da dignidade da outra). Diferentemente, o pressuposto desse princípio fundamental impõe concretização 
radical; ele logicamente não admite atenuação. Se afastado, nada sobra do princípio da dignidade. E esse princípio, se pudesse ser totalmente eliminado, não seria princípio fundamental. O preceito da intangibilidade da vida humana, portanto, não admite exceção; é absoluto e está, de resto, confirmado pelo caput do art. $5^{\circ}$, da Constituição da República. Vejamos algumas de suas concretizações.

Deixando de lado o que ninguém contesta, a licitude da suspensão do "empenho terapêutico" 19 a primeira concretização da intangibilidade da vida humana, no campo polêmico de hoje, há de ser a proibição da eutanásia (dita, às vezes, "eutanásia-direta"). O médico que concorda em praticar a eutanásia, porque o interessado declarou vontade nesse sentido, está admitindo implicitamente a falta de valor intrínseco da vida de seu paciente. Como diz Montero ("Rumo a uma legalização..." 1998): "É claro que o fundamento não reconhecido da eutanásia se baseia na idéia de que algumas vidas não valem (mais) a pena serem vividas. A decisão de praticar a eutanásia não se apóia nunca apenas na vontade do doente, mas é sempre o resultado de um juizo de valor sobre a qualidade de vida" O próprio suicídio fere o princípio da intangibilidade da vida humana, porque não há, quanto à vida, jus in se ipsum - na qualificação "lícito/ilícito". é ato ilícito, ainda que sem sanção. Toda vida individual se insere no fluxo vital coletivo, de tal forma que o titular não é o soberano absoluto de sua vida; a vida de cada um é valor que, mediatamente, a todos interessa.

Uma segunda concretização da intangibilidade da vida humana é a proibição do abortamento do embrião, isto é, a interrupção voluntária da gravidez. A célula una (zigoto), resultante da fusão dos gametas e, em seguida, multiplicada por desenvolvimento interno no ventre materno, é, sem dúvida, um novo ser humano que já recebeu sua própria parcela de vida, já se inseriu com individualidade no fluxo vital contínuo da natureza humana. Tem vida própria e, no mínimo, capacidade para ser amado. Filosoficamente, ou eticamente, é, pois, pessoa humana. Do ponto de vista jurídico, pode não ter "personalidade civil" (art. $4^{\circ}$ do Código Civil e art. $2^{\circ}$ do novo Código), mas já é sujeito de direito (art. $4^{\circ}$, última parte, do Código Civil e art. $2^{\circ}$ última parte, do novo Código). Constitucionalmente, não há, por fim, como negar que

19. Catccismo da Igrcja Católica (cdição francesa, ns. 2.278/2.279): “A cessação dos procedimentos médicos onerosos, perigosos, extraordinários ou desproporcionados em relação aos resultados esperados, pode ser legitima. É a recusa do "cmpenho terapêutico". Ninguém, assim, quer dar a morte; somente aceita de não a poder impedir". No original: "La cessation de procédures médicales onéreuses, périlleuses, extraordinaires ou disproportionnées avec les résultats attendus, pcut ĉtre légitimc. C'cst lc refus de "l'acharnement thérapcutique" On ne veut pas ainsi donner la mort; on accepte de ne pas pouvoir l'empêcher". E o texto continua: Les decisions doivent être prises par le patient s'il en a la compétence el la capacité, ou sinon par les ayants droit légaux, en respectant toujours la volonté raisonnable et les intérêts légitimes du patient.

Même si la mort est considérée comme imminente, les soins ordinairement dus à une personne malade ne peuvent être légitimement interrompus. L'usage des analgésiques pour alléger les souffrances du moribond, même au risque d'abréger ses jours, peut être moralement conforme à la dignité humaine si la mort n'est pas volue, ni comme fin ni comme moyen, mais seulement prévue et tolérée comme inévitable. Les soins palliatifs constituent une forme privilégiée de la charité désintéressée. A ce titre ils doivent être encouragés" (reforços gráficos nossos). 
o feto assim constituído está protegido tanto pelo princípio da dignidade da pessoa humana que pressupõe o direito à vida quanto pelo caput do art. $5^{\circ}$, da Constituição da República. $^{20}$

Por outro lado, do embrião pré-implantatório, resultante de processos de fecundação assistida, ou até mesmo de clonagem, constituído artificialmente e que ainda está fora do ventre materno, por não estar integrado no fluxo vital contínuo da natureza humana, é dificil dizer que se trata de "pessoa humana" É verdade que, por se tratar da vida em geral e especialmente de vida humana potencial, nenhuma atividade gratuitamente destruidora é moralmente admissível mas, no nosso entendimento, ai já não se trata do princípio da intangibilidade da vida humana; trata-se da proteção, menos forte, à vida em geral. Dentro desses parâmetros, isto é, sob o ângulo da intangibilidade da vida humana, a própria clonagem terapêutica, como admitida pelo Parlamento Europeu e pelo Governo inglês, não é condenável do ponto de vista ético e jurídico. ${ }^{21}$

Uma terceira concretização da intangibilidade da vida humana como pressuposto do princípio constitucional da dignidade (e, aqui, garantida expressamente pela letra "a" do inciso XLII do art. $5^{\circ}$, da Constituição da República) é a impossibilidade da introdução legislativa da pena de morte. Considerando que, pelas condições de hoje, a eliminação física não é a única forma de sanção capaz de evitar um mal maior, isto é, de evitar outras mortes (seria, em tese, a única hipótese em que caberia a pena de morte) e não havendo nenhum outro valor juridico superior à vida humana, a pena de morte no Direito Penal comum é inconstitucional.

Depois da intangibilidade da vida humana, a primeira consequiência direta que se pode tirar do princípio da dignidade é o respeito à integridade fisica e psíquica da pessoa humana. Pode o Poder Público "invadir" a condição natural do ser humano

20. Do acordo com o que está cscrito no texto, o chamado "aborto sentimentul", cmbora não punívcl pelo Código Pcnal de 1940, ć constitucionalmente um ato ilicito. A gravidez indescjada, resultante dc cstupro, infelizmentc, põc $\mathrm{cm}$ conflito dircitos relevantíssimos mas, logicamente, tem-se que reconhecer que o valor maior ć o valor da vida humana. A decisão de abortamento climina a vida c, cm decorrência, como disscmos, climina também toda c qualquer dignidade (valor) da pessoa climinada; a. de nãoabortamento ferc, por hipótcsc, a dignidadc da mãc, mas, certamentc, não climina cssa dignidade. Essc abortamento ć, pois, ato ilícito, ainda que não punível. $O \$ 1^{\circ}$ do art. $4^{\circ}$ da Convenção da Costa Rica dispõc: "Toda pessoa tem direito de que se respeite sua vida. Esse direito deve ser protegido pela lei, e, em geral, desde o momento da concepção. Ninguém pode ser privado da vida arbitrariamente". Difcrentcmente, na gravidez que põc $\mathrm{cm}$ risco a vida da mãc, considerando que ncle há "visla humana $x$ vida humana". abortamento não ć ato ilícito; não ć caso de exccção ao preccito da intangibilidade da vida humana.

21. Procurando no multissccular arscnal da experiência jurídica uma situação que possa servir como basc para o raciocínio analógico, há o caso do Digesto $19,1,17$; a comparação talvez scja um pouco grotesca mas, do ponto de vista da analogia, parece ter pertinência. O cmbrião pré-implantatório seria como o material de construção cmpilhado no terreno; cle ainda não ć a casa (art. 49 do Código Civil c art. 84 do novo C. Civil; ć bcm móvel, c não, imóvel). Já o cmbrião retirado do ventre materno, para mclhoria genética c posterior reimplante, sc isto for possível, scria semelhante ao matcrial retirado da casa, para postcrior reaproveitamento, o qual juridicamente não perde sua condição de imóvel (art. 46 do Código Civil). Em latim (Ulpiano): "ea quae ex aedificii detracta sunt, ut reponantur, aedificii sunt; at quae parata sunt, ut imponantur, non sunt aedificii" 
e obter à força amostras de sangue para fins de prova? Pode realizar à força transfusões de sangue? Uma "sacralidade" do corpo, à semelhança da intangibilidade da vida humana, existe? Sim, existe essa "sacralidade" do corpo, mas não tão forte quanto a da vida, até porque estamos agora em pleno terreno dos princípios jurídicos, cujos preceitos nunca são imperativos categóricos.

O exame de DNA, no campo civil, não pode, por exemplo, ser imposto manu militari; caberiam aqui outros meios de prova, como presunção e indícios, a serem utilizados livremente pelo julgador. Não parece ser suficiente o interesse privado no conhecimento da paternidade para quebrar o preceito da não-invasão física; a permissão poderia se tornar precedente excessivamente grave, valendo como abertura de caminho para abusos posteriores. ${ }^{22}$ Por outro lado, no campo penal, diferentemente, por força do interesse público na apuração de um crime, o exame forçado poderia ser admitido.

Por sua vez, a decisão do paciente de autorizar ou não que lhe façam transfusão de sangue, tal qual a de se submeter ou-não a operações cirúrgicas de risco, parece pertencer ao campo da autonomia (não se trata aqui da intangibilidade da vida, como no caso da eutanásia). A hipótese muda de figura quando se trata de representante de outra pessoa, por exemplo, de pai em relação a filho menor - aqui não há direito discricionário do representante; a transfusão de sangue, ou a operação, diante da impossịbilidade de manifestação de vontade útil do paciente, deverá ser feita, ou não, segundo as normas técnicas.

Ponto fundamental do respeito à integridade fisica e psíquica é o da obrigação de segurança. Os autores nacionais parece que ainda não se conscientizaram de que a obrigação de segurança, tão firmemente referida nos arts. $8^{\circ}, 9^{\circ} \mathrm{e} 10$ do Código de Defesa do Consumidor (Seção: "Da proteção à saúde e segurança"), tem sede constitucional, seja como decorrência do princípio da dignidade, seja por força do caput do art. $5^{\circ}$ da Constituição. A obrigação de segurança hoje se "autonomizou"; existe independentemente de contrato - pode não haver contrato nem muito menos importa se o contrato é gratuito ou oneroso (transporte pago ou não, hospedagem, serviços em geral etc). A obrigação de segurança existe sempre; os danos à pessoa devem ser indenizados. É importante dizer: em matéria de danos à pessoa, a regra é hoje a responsabilidade objetiva. A responsabilidade subjetiva, nesse campo, é atualmente a exceção. A responsabilidade objetiva, na obrigação de segurança, surge agora diretamente da Constituição (não é da lei ou da Jurisprudência); somente haverá responsabilidade subjetiva quando houver lei expressa (por exemplo, na responsabilidade médica - na qual, assim mesmo, há inversão do ônus da prova, porque a prova deve ser feita por quem tem melhores condições para a fazer). A admissão da responsabilidade subjetiva como exceção à responsabilidade objetiva constitucional é admissível, porque os preceitos decorrentes dos princípios juridicos não são absolutos.

Além da vida em si e da integridade física e psíquica, a concretização da dignidade humana exige também o respeito às condições mínimas de vida (segunda 
conseqüência direta do princípio). Trata-se aqui das condições materiais de vida. A obtenção da casa própria e a sua proteção, por exemplo, são decorrências da dignidade humana. Embora a Lei n. 8.009/90 traga como ementa a impenhorabilidade do "bem de familia", e, em seu art. $1^{\circ}$ somente se refira a "imóvel residencial próprio do casal ou da entidade familiar". está correto o entendimento do STJ de que a proteção cabe antes ao ser humano como tal que à família - o aprimoramento ético leva a isso. "Penhora Lei n. 8.009/90. Solteiro deve merecer o mesmo tratamento. A Lei n. 8.009/90, artigo $1^{\circ}$, precisa ser interpretada consoante o sentido social do texto. (omissis). Data venia, a Lei $n$. $8.009 / 90$ não está dirigida a número de pessoas. Ao contrário - à pessoa. Solteira, casada, viúva, desquitada, pouco importa. O sentido social da norma busca garantir um teto para cada pessoa. Só essa finalidade, data venia, põe sobre a mesa a exata extensão da Lei. Caso contrário, sacrificar-se-á a interpretação teológica para prevalecer a insuficiente interpretação literal. (STJ-Ac. unân. da $6^{\prime \prime}$ T., publ. em 20.09.99-Resp. 182.223-SP - Rel. Min. Vicente Cernicchiaro)" (Cumpre dizer, entre parêntesis, que o STJ não se reiere à Constituição da República por causa das conhecidas conseqüências processuais sobre competência). ${ }^{23}$ A Corte de Cassação da França (19 de janeiro de 1995) também já decidiu que "a possibilidade para qualquer pessoa de dispor de uma casa decente é um objetivo constitucional" (apud Heymann-Doat, p. 149).

Justificam-se, pelo mesmo espírito de respeito às condições mínimas de vida, inúmeras normas como as de impenhorabilidade (especialmente os incisos II, IV, VI, VII e X do art. 649 do Código de Processo Civil, ou seja, provisões para manutenção por um mês, salários, instrumentos profissionais, pensões, imóvel rural até um módulo), a proibição de doar todos os bens, ${ }^{24}$ as que dão direito a alimentos, as que prevêem estado de necessidade, ${ }^{25}$ as que concedem direito real de habitação e as que isentam o benefício do seguro de vida das obrigações ou dívidas do segurado.

No campo contratual, o respeito às condições mínimas de vida também tem aplicação. Segundo a teoria alemã dos "limites do sacrifício" os contratos não precisam ser cumpridos quando sua execução leva a gastos excessivos não previstos, o que terá maior razão de ser quando o adimplemento puder dificultar a sobrevivência. Também, ao que nos informa Nobre Filho ("O Direito Brasileiro e...", p. 16), com base em Ernesto Benda, no campo administrativo, o Tribunal Constitucional alemão ordena o respeito às condições de sobrevivência: "Assim, de acordo com tal preceito, afigurase inadmissivel que o administrado seja despojado de seus recursos indispensáveis à sua existência digna, de sorte que a intervenção estatal na propriedade, pela via fiscal ou não, não deverá alcançar patamares capazes de privá-lo dos meios mais elementares de subsistência. De modo igual, o citado art. 1.1 traduz, em detrimento dos poderes públicos, a obrigação adicional de prover ao cidadão um mínimo existencial"

23. Há outras decisões; por excmplo, a do l" Tribunal de Alçada Civil de São Paulo publicada no Bolctimi da AASP n. 2105 de $3 . I X .99$ (n. 5 do Ementário).

24. Cf. Luiz Edson Fachin, "Estatuto Jurílico do Patrimônio Minimo", passim.

25. A necessidade cria dircito (Cf. Alain Sayag, "Essai sur le besoin createur de droit", passim). 
Pio XII, por sua vez, na rádio-mensagem do Natal de 1942, estabelece relação entre dignidade humana e o direito à propriedade privada. "Deus, ao abençoar nossos pais, disse: 'Crescei e multiplicai-vos; enchei a Terra e submetei-a' E disse depois ao primeiro chefe de família: 'Comerás o pão mediante o suor de teu rosto'. A dignidade da pessoa humana exige, pois, normalmente, como fundamento natural para viver, o uso dos bens da terra, ao qual corresponde a obrigação fundamental de normas juridicas positivas, reguladoras da propriedade privada. As normas juridicas positivas reguladoras da propriedade privada podem modificar é conceder um uso mais ou menos limitado; mas se querem contribuir à pacificação da comunidade, deverão impedir que o trabalhador que é ou será pai de familia se veja condenado a uma dependência e escravidão econômica inconciliável com seus direitos de pessoa" 26

Grosso modo, o pressuposto e as conseqüências do princípio da dignidade (art. $1^{\circ}$, III, da C.R.) estão expressos pelos cinco substantivos correspondentes aos bens jurídicos tutelados no caput do art. $5^{\circ}$ da C. R.; são eles: vida (é o pressuposto), segurança (primeira conseqüência), propriedade (segunda conseqüência) e liberdade e igualdade (terceira conseqüência), sendo o pressuposto, absoluto e as conseqüências, "quase absolutas".

Finalmente, a terceira conseqüência do princípio da dignidade é a consistente no respeito aos pressupostos minimos de liberdade e convivência igualitária entre os homens (condições culturais). Excluindo o direito à vida e o direito à integridade física e psíquica, já tratados, relacionam-se com esta conseqüência os demais "direitos de personalidade" - mas não em todos os seus aspectos e, sim, nos aspectos fundamentais; são, aqui, direitos que se prendem ao livre desenvolvimento da pessoa humana no seu meio social. A título de exemplo, lembramos as seguintes concretizações:

a. direito à identidade, especialmente direito ao nome. Trata-se de ter identidade e nome. No século XIX, segundo Heymann-Doat ("Libertés publiques", p. 145), a prisão era um "espaço extra-legal", dai a seguinte quebra de dignidade humana: "não deixar penetrar no recinto da prisão os nomes dos condenados... e dar a cada detento um número bem visivel que fique preso no braço direito" E a autora continua: "Era privar os prisioneiros do direito mais elementar da pessoa, o direito a um nome" 27 No tema de registro civil, a França foi condenada pela Corte Européia dos Direitos do

26. No original espanhol: "Dios, al bendecir a muestro progenitores, les dijo: 'Creced y multiplicaos y henchid la tierra y dominadla' $\gamma$ dijo después al primer jefe de familia: 'Mediante el sudor de tu rostro comcrás cl pan'. La dignidade de la persona humana exige, pues, normalmente, como findamento natural para vivir, el derecho al uso de los bienes de la tierra, al cual corresponde la obligación findamental de normas juridicas positivas, reguladoras de la propiedad privada. Las normas juridicas positivas, reguladoras de la propriedad privada, pueden modificar y conceder un uso más o menos limitado; pero, si quieren contribuir a la pacificación de la comunidad, deberán impedir que el obrero que es o será padre de familia se vea condenado a una dependencia y esclavitud económica inconciliable con sus derechos de persona" ("Doctrina Pontificia", II).

27. No original: "ne pas laisser pénétrer dans l'enceinte de la prison les noms des condamnés... et donner à chaque détenu un número très apparent qu'il porte attaché au bras droit. C'était priver les prisonniers du droil le plus élémentaire de la persone, le droit à un nom" 
Homem, no "affaire B. XF.", em 25 de março de 1992, por se recusar a alterar o estado civil de um transexual (apud Heymann-Doat, p. 147).

b. direito à liberdade. Em decisão sobre prisão em alienação fiduciária já se decidiu: “A liberdade é o maior bem da vida, por isso mesmo sobrepaira ao interesse pecuniário de qualquer credor. Só em último caso deve-se prender o cidadão comum, que confia sua própria liberdade ao credor, fortalecido pela lei para explorar atividade econômica considerada útil ao desenvolvimento do País" (Des. Cristiano Graef Júnior, in RJTJRGS - v. 77, p. 143)" São contrárias à dignidade, sob esse aspecto da liberdade (liberdade natural), as cláusulas de tempo excessivo de prestação de serviço. ${ }^{28}$ Eventualmente, também as cláusulas abusivas de exclusividade e de nãoconcorrência podem ferir o direito à liberdade. ${ }^{29}$

c. direito à igualdade. Serve de exemplo o conhecido "caso do anão", na França, que consistiu no fato de que, na comuna de Morsang-sur-Orge, distrito da cidade de Aix-en-Provence, o prefeito proibiu um espetáculo realizado em casa noturna, em que o "jogo" consistia no lançar, de um grupo de péssoas para outro, um anão - este, por dinheiro, aceitava participar da "brincadeira" O Conselho de Estado, em decisão de 1995, contrária a todos os particulares envolvidos, deu como legítima a proibição feita pelo prefeito; o anão estava sendo tratado como coisa. Também em alguns programas de auditório, no Brasil, a condição "desfrutável" com que o apresentador trata a pessoa que ali está fere a dignidade, nesse capítulo da igualdade básica dos seres humanos.

d. direito à intimidade, ao sigilo de correspondência etc. A Corte Européia dos Direitos do Homem desenvolveu o direito à intimidade, compreendendo nele a vida sexual. Quanto à correspondência, o art. $5^{\circ}$, XLIX, da Constituição da República determina: "é assegurado aos presos respeito a integridade fisica e moral" e, de fato, pelo princípio da dignidade da pessoa humana, todo preso deve ser tratado com Humanidade; ora, segundo decisão da Corte Européia dos Direitos do Homem, no "affaire Fell et Burger", de 25 de março de 1983, os presos também têm direito ao respeito de sua correspondência (apud Heymann-Doat, p. 146).

Sintetizando tudo que procuramos transmitir com este artigo, conclúímos: a. diante da "confusão geral" criada por gregos e troianos na utilização do princípio jurídico da dignidade da pessoa humana, impõe-se ao jurista brasileiro, evitando uma axiologia meramente formal, dar indicações do conteúdo material da expressão; b. há graves falhas científicas na concepção filosófica da pessoa humana como ser dotado de razão e vontade, ou auto-consciente (concepção insular). Segue-se daí que é insuficiente a idéia de dignidade como autonomia, a que essa concepção dá sustentação. A pessoa humana, na verdade, se caracteriza por participar do magnifico fluxo vital da natureza (é seu gênero mais amplo), distinguindo-se de todos os demais seres vivos

28. Cf. art. 1120 do C. Civil c art. 598 do novo C. Civil.

29. Sobre cssas cláusulas abusivas, mas vistas sob ângulos diferentes (abuso de dircito, fatores cconômicos ctc), Le Gac-Pech, "La proportionnalité en droit privé des contrats" pp. I6I c ss. a pp. 189 c ss. 
pela sua capacidade de reconhecimento do próximo, de dialogar, e, principalmente, pela sua capacidade de amar e sua abertura potencial para o absoluto (é sua diferença específica) (concepção da pessoa humana fundada na vida e no amor); c. com esse fundamento antropológico, a dignidade da pessoa humana como princípio jurídico pressupõe o imperativo categórico da intangibilidade da vida humana e dá origem, em seqüência hierárquica, aos seguintes preceitos: 1. respeito à integridade física e psiquica das pessoas; 2. consideração pelos pressupostos materiais mínimos para o exercício da vida; e 3. respeito às condições mínimas de liberdade e convivência social igualitária.

São Paulo/Ouro Preto, outubro de 2001.

Bibliografia.

"Catecismo da Igreja Católica" - ed. francesa "Catéchisme de L'Eglise Catholique" Mame-Plon, 1992.

CHANGEUX, Jean-Pierre e RICOEUR, Paul - "Ce qui nous fait penser: La Nature et la Règle”, Odile Jacob, Paris, 2000 (a $1^{\text {a }}$ edição é de 1998).

COMPARATO, Fabio Konder - "A Afirmação Histórica dos Direitos Humanos" 2a. ed. rev. e ampl., Saraiva, São Paulo, 2001.

DAMÁSIO, Antônio - “O Mistério da Consciência”, trad. Laura Teixeira Motta, rev. técnica de Luiz Henrique Martins Castro, Cia. das Letras, São Paulo, 2000 (título original: "The Feeling of What Happens - Body and Emotion in the Making of Consciousness", 1999).

DAWKINS, Richard - "The Selfish Gene" $5^{\text {a }}$ ed., Oxford Univ. Press, Oxford/ New York, 1999 (a 1ª ed. é de 1976).

DE WAAL, Frans - "Good Natured: the Origins of Right and Wrong in Humans and Other Animals", Harvard Univ. Press, Cambridge, 1996.

DESCARTES, René - "Discours de la Méthode", com intr. e notas de Etienne Gilson, J. Vrin, Paris, 1954 (a $1^{\text {il }}$ edição é de 1637).

ENGISH, Karl - "Introdução ao Pensamento Juridico", trad. De J. Baptista Machado, Gulbenkian, Lisboa, 1988 (título original: "Einfürhung in das juristiche Denken", 1977; a $1^{\circ}$ ed. é de 1956).

FACHIN, Luiz Edson - “Estatuto Juridico do Patrimônio Minimo”, Renovar, Rio de Janeiro, 2001.

GOLDSMITH, Timothy H. - "The Biological Roots of Human Nature: Forging Links Between Evolution and Behavior", Oxford Univ. Press, New York/ Oxford, 1994 (a l: ed. é de 1991). 
GONTIER, Thierry - "De l'homme à l'animal: Paradoxes sur la nature des animaux. Montaigne et Descartes", J. Vrin, Paris, 1998.

HEYMANN-DOAT, Arlette - "Libertés publiques et droits de l'homme", 4" ed., L.G.D.J, Paris, 1997.

JONAS, Hans - "Le principe responsabilite" trad. francesa de Jean Greisch, $3^{\text {a }}$ ed., Flammarion, Paris, 1995 (titulo original: "Das Prinzip Verantwortung" 1979).

KANT, Emmanuel - "Fondements de la metaphysique des moeurs" obra seguida da "Critique de la raison pratique" trad. francesa de J. Barni, Liv. Philosophique de Ladrange, Paris, 1848 (título original: "Grundlegung zur Metaphisik der Sitten" 1785).

LARENZ, Karl - "Derecho justo: fundamentos de ética juridica", trad. e apres. de Luís Díez-Picazo, Civitas, Madri, 1985 (título original: "Richtiges Recht-Grundzüge einer Rechtsethik" 1978).

LEAKEY, Richard - "L'origine de l'Humanite", trad. francesa de Jean - Pierre Ricard, Le Grand Livre du Mois, Paris, 1998 (titulo original: "The Origins of Humankind" 1994).

LE GAC-PECH, Sophie - "La proportionnalité en droit privé des contrats" L.G.D.J., Paris, 2000.

MASTERS, Roger D. e McGUIRE, Michael T. - "The Neurotransmitter Revolution: Serotonin, Social Behavior, and the Law" Southern Illinois University Press, Carbondale e Edwardsville, 1994.

McGUIRE, Michael T. e MASTERS, Roger D. - Vide Masters, Roger D.

MIRANDA, Jorge - "Manual de Direito Constitucional" Tomo IV, 2" ed. rev. e actualizada, Coimbra Ed., Coimbra, 1993.

MONTERO, Etienne - "Rumo a uma legalização da eutanásia voluntária? Reflexões sobre a tese da autonomia" in "Cahiers de la Faculté de Droit de Namur" (Bélgica), n. 3, 1998.

NOBRE JÚNIOR, Edilson Pereira - "O Direito Brasileiro e o Principio da Dignidade da Pessoa Humana", in Revista "Lex" n. 266, fev. de 2001.

PAULO VI - "Declaração Dignitatis Humanae Sobre a Liberdade Religiosa" - Documentos do Vaticano II, Ed. Vozes, Rio, 1996 (edição bilingüe latina-portuguesa, com texto em português, revisto pela CNBB).

PIGNEDOLI, Valeria - "Privacy e libertà religiosa" Giuffrè, Milão, 2001.

PIO XII - Rádio-mensagem do Natal de 1942 ("Con sempre"), versão em espanhol, in "Doctrina Pontificia II" BAC, Madri, 1958. 
RICOEUR, Paul e CHANGEUX, Jean-Pierre - Vide Changeux, Jean-Pierre.

SAYAG, Alain - "Essai sur le besoin createur de droit", L.G.D.J., Paris, 1969.

SOMMA, Alessandro - "Lo status dell' animale" (cap. XIV do "Corso di Sistemi Giuridici Comparati" a cura di Guido Alpa), Giappichelli Ed., Turim, 1996.

WOJTYLA, Karol - "Persona y acción" trad. espanhola de Jesus Fernandez Zulaica, B.A.C., Madri, 1982 (título da edição original: "Osoba e Czyn" Título da ed. definitiva: "The Acting Person" 1980. O texto definitivo foi estabelecido pelo autor com a colaboração de Anna-Teresa Tymienicka). 